\title{
Residents' Perception and Response Patterns To Climate Change Impacts in Peri Urban Areas of Ibadan, Nigeria
}

\author{
${ }^{1}$ Kehinde, O. J ; ${ }^{2}$ Olaleye, E. O; ${ }^{3}$ Toyobo, E. A and ${ }^{4}$ Oginni, E. O \\ 1 \& 3: Urban and Regional Planning Dept. LAUTECH, Ogbomoso, Nigeria \\ 2: First Bank Nigeria Plc; 4: Federal Radio Corporation of Nigeria Amuludun FM 99.1 Moniya, Nigeria. \\ E-mail of Corresponding author: olamijukehinde@gmail.com
}

\begin{abstract}
Variations in climate, one would expect to be perceived differently among people of different socioeconomic background and social strata. However, with the people of Akinyele LGA in Oyo state, the case is different where perception of the causes, evidences and response patterns to the impacts of climate change do not show any variation that can be linked with socio-economic attributes across the political wards. A total of eight out of twelve political wards/health districts were purposively selected (being most rural with rapid transformation) where about 300 questionnaires were administered with a random systematic approach.

Data collected were analysed using simple descriptive analytical tool. The hypotheseswere tested with Chisquare. The study reveals that causes and evidences of climate change are not significantly different across political wards except for fluctuations in food production and supplies, over-cropping, overgrazing, settlement expansion and excessive dryness with p-value of 0.012, 0.048, 0.049, 0.019 and 0.018 respectively.

There is therefore urgent need for implementation of tree planting and landscape planning initiatives, farm practice improvement and re-introduction of neighbourhood parks and gardens so as to forestall the growing vulnerability of residents to climate change impacts and to enhance social integration, a vital ingredient to building community's resilience.
\end{abstract}

Keywords:Climate change; Environmental Education, Global warming and Greenhouse Effects.

\section{Introduction}

The earth which was once a beautiful habitation for man, other living and non living organisms in the past now wears a dreadful look owing to the shifting patterns of sea-ice, winter snows and changes in the mean position of storm tracks; changes in the location and extent of desert regions; accumulation heat trapping Greenhouse gases (GHGs) among others and increasing environmental unfriendly human activities (Kellogg and Schneider, 1977; Goudie, 1983; and Burrow, 1998).

Apart from the latter, the above-mentioned causes of climate change are natural occurring though their paces have been influenced by human activities recently. However, the increasing human induced causes have enhanced the natural causes and are doing even more on their own (though they are reversible at times) (WMO/UNEP, 1986; Jenkins and Ephraums, 1990; Leggett, 1990; Bush, 2000; and Cunningham, 2004). Given the existing rate of urbanisation, an economy that is largely land-based, poor technology and literacy rate, and hard biting poverty, it cannot be over-emphasised that efforts/actions geared at salvaging both present and future generations from the consequences of our actions and inactions must start now (Olorunfemi and Adeyemi, 1994; Jones, Arnott and Douglass, 1998; Adelekan and Gbadegesin, 2004).

Environmental issues at the grass root have not gained wide publicity in most Sub-Saharan African countries especially in Nigeria. Therefore, the consciousness of which eco-friendly activities to embrace is still shallow and calls for environmental education. The understanding of the persistent fluctuations in climate is still negatively skewed owing to high level of illiteracy, poor socio-cultural dispositions and mystification of scientific and physical evidences of change in climate among local people (Ogundipe, 2006; Adeboyejo et. al., 2011). The effects of change in climate have manifested in incessant water shortages, apparent heat waves, loss of land and soil fertility and shortages in the production and supplies of food to mention but few (Pearce, 1996; Kate and Torrie, 1998 and African Development Bank (ADB), 2001).

Residents' response patterns to the impacts of climate change in most peri-urban areas of Nigeria have been unhealthy and endemic. There is therefore, an aggravation of existing sufferings of the people. The periurban poor have lost their resilience (because of their landlessness, loss of farmlands, forests and water bodies among others) to incongruous uses, expansion of settlements and road constructions. The aftermath of some of these effects include: forced eviction and migration, prevalence of abject poverty and diseases, dilapidation of existing infrastructure, adoption of poor strategies to cope with impacts of climate change (Bayero, 2004; Fuwape; 2004 and Shah, 2007). 
It is against this backdrop that this study seeks to examine residents' perception and response patterns to the impacts of climate change in Akinyele, LGA of Oyo state, Nigeria. This is with a view to suggesting sustainable coping strategies among communities whose livelihoods are largely affected so as to enhance their capacity to further cope. The specific objectives of this study are to: (i) examine residents' socio-economic activities in Akinyele LGA with high capacity of inducing climate change; (ii) analyse residents' perception of the causes and evidences of climate change; (iii) evaluates residents' response patterns to the evidences and problems of climate change; and (iv) suggest probable solutions to enhance residents' abilities to reduce the negative impacts of climate change at the best and/or to cope with them at the worst. The hypothesis was tested with Chi-square that causes, evidences and response patterns to the impacts of climate change are not significantly different across health districts/political wards.

\section{a) Brief of the Study Area}

\section{Material And Methods}

The General OlusegunObasanjo local government reform of 1976 was responsible for the creation of Akinyele as one of the constituted local government areas (LGAs) in the old Oyo State. With its seat of administration at Moniya, the local government comprising of twelve health districts/political wards span across a number of villages of various spatial extent and population. Notable among these villages are: Ikereku, Olanla, Olode, Akinyele, Moniya, Ajibode, Irepodun, Iwokoto, Talontan, Ojoo, Ajibade, Ijaye, Okegbemi, and Iroko to mention a few. The 2006 National Population Census puts the population of the LGA at 211,359 people.
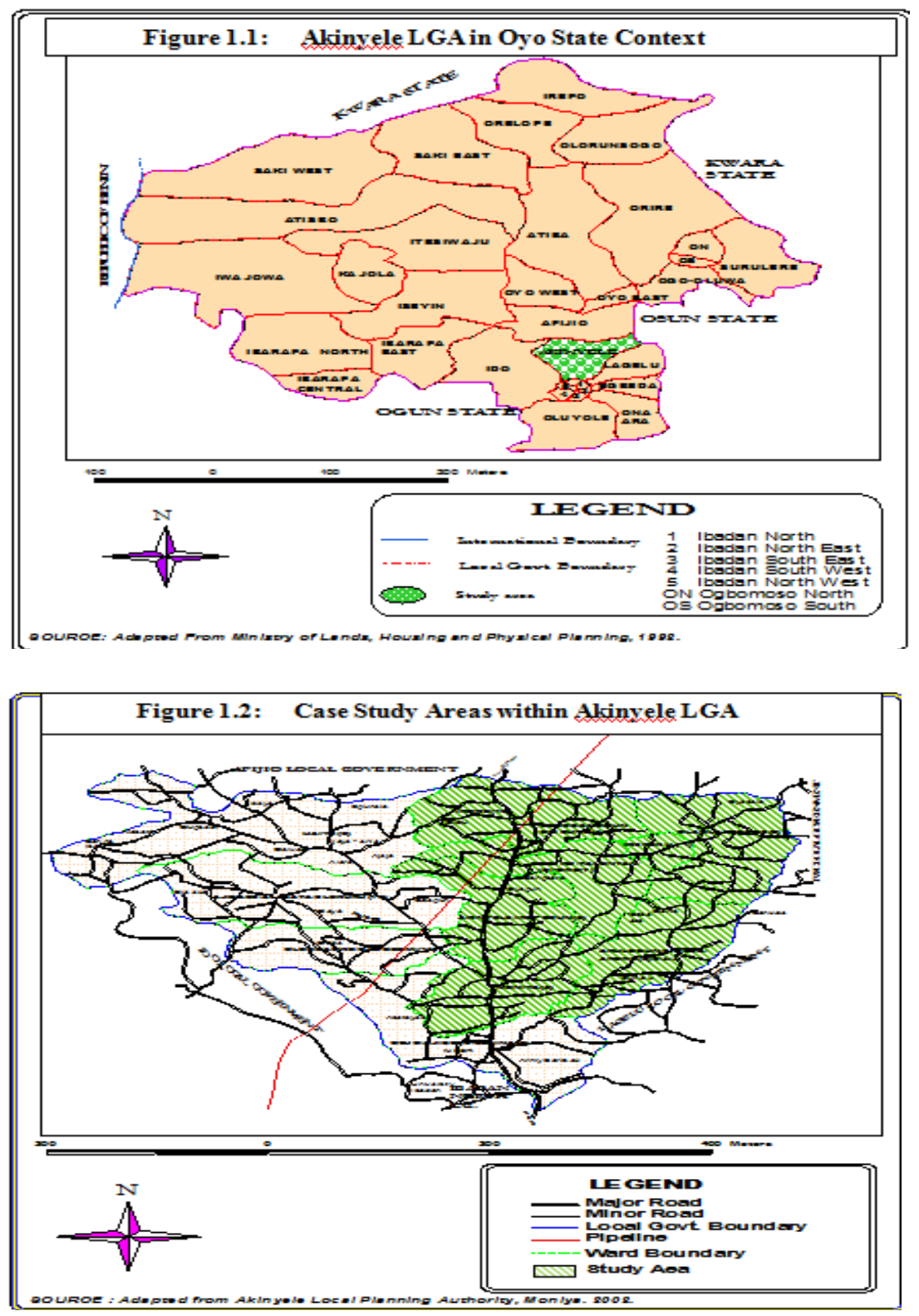


\section{b) Methods of Data Collection}

Data were collected through primary and secondary sources. The primary data include responses on fluctuations of food production and supplies, temperature change, land and soil fertility loss, access to safe drinking water and sanitation, and residents' socio-economic characteristics. These were processed from information gathered through 300 random systematically administered questionnaires within the localities.

The targeted population werehousehold heads from eight out of twelve health districts/political wards. From the foregoing, residents' perception of the causes and evidences of, as well as response patterns to the impacts of climate change were cross-examined across the study area.

\section{c) Method of Data Analysis}

The information extracted from the questionnaire administration were analysed and explained through descriptive statistics. Suggestions were made based on the findings in the study area. The hypothesis was tested using Chi-square to explain the significant difference (if any) in residents' perception of causes and evidences of climate change as well as response patterns to emanating impacts within the study area.

\section{a) Socio-economic characteristics of Respondents}

\section{Results And Discussion}

Majority of the respondents were males $73.0 \%$ while the remaining $27.0 \%$ were females. About $49.0 \%$ of the respondents were in the age bracket 41-60years, while $35.0 \%$ and $16.0 \%$ were aged $20-40$ years and 61 years and above respectively. The study reveals that about $43.0 \%$ of the respondents were illiterate, those that had primary education were about $22.0 \%$, secondary education $39.0 \%$ and post secondary education $6.0 \%$.

The respondents were engaged in different types of occupation such as: trading $29.0 \%$, farming $19.3 \%$, self employed $16.0 \%$, transportation $12.7 \%$, agro-allied merchants $17.0 \%$, and civil service $6.0 \%$. About $68.0 \%$ of the respondents' monthly incomes were below N8, 000, 26.0\% of them receives between N8, 001 and N18, 000 while about $6.0 \%$ of them receives income between N18, 001 and above. The study also reveals that largest proportion of the respondents $65.6 \%$ have lived in their communities for between $21-40$ years, $28.0 \%$ of them have lived in their communities for between 0 and 20 years, while $6.4 \%$ have stayed for between 41 years and above.

This implies the presence of low income earners coupled with low level of education, factors which contribute to poor awareness of and resilience to the impacts of climate change in the study area.

\section{b) Residents' Awareness of the causes and evidences of climate change}

Most of the respondents, about $65.0 \%, 85.7 \%, 86.7 \%$ and $97.6 \%$ agreed that deforestation, overgrazing, settlement expansion and over-cropping were significant causes of climate change respectively in their communities. However, about $53.4 \%$ and $84.0 \%$ of the respondents disagreed that population increase and emission of greenhouse gases respectively were causes of climate change in their localities (see table 1).

Alternatively, majority of the respondents, about $92.0 \%, 66.0 \%$ and $72.0 \%$ confirmed that reduction in number of days of rainfall, frequent flooding and shrinking sizes of water bodies respectively were evidences of climate change in their localities. About $78.7 \%$ and $68.0 \%$ of them also testified that there have been reduction in rate of food production and decline in water supplies respectively.

However, $88.7 \%$ and $52.6 \%$ of the respondents declined that there were evident excessive dryness and loss of land and soil fertility respectively in their communities (see table 1).

Table 1:Residents' Awareness of Climate Change

\begin{tabular}{|c|c|c|c|}
\hline \multirow[t]{2}{*}{ Awareness of Climate Change } & \multicolumn{2}{|c|}{ Responses } & \multirow[t]{2}{*}{ Test Results (p-value) } \\
\hline & Yes $(\%)$ & No $(\%)$ & \\
\hline Causes of Climate Change & & & \\
\hline Deforestation & 65.0 & 35.0 & 0.609 \\
\hline Population Increase & 45.7 & 54.3 & 0.948 \\
\hline Overgrazing & 85.7 & 14.3 & $\underline{0.049}$ \\
\hline GHGs accumulation & 16.0 & 84.0 & $\overline{0.304}$ \\
\hline Settlement Expansion & 86.7 & 13.3 & $\underline{0.019}$ \\
\hline Over-cropping & 97.6 & 2.4 & $\underline{\underline{0.048}}$ \\
\hline
\end{tabular}




\begin{tabular}{llrr}
\hline Evidences of Climate Change & & $\mathbf{8 8 . 7}$ & $\mathbf{0 . 0 1 8}$ \\
\hline Excessive Dryness & $\mathbf{1 1 . 3}$ & $\mathbf{8 . 0}$ & $\mathbf{0 . 3 0 6}$ \\
Reduced no. of days of rainfall & $\mathbf{9 2 . 0}$ & $\mathbf{3 4 . 0}$ & $\mathbf{0 . 9 3 1}$ \\
Frequent Flooding & $\mathbf{6 6 . 0}$ & $\mathbf{5 2 . 6}$ & $\mathbf{0 . 8 3 0}$ \\
- $\quad 47.4$ & $\mathbf{2 8 . 0}$ & $\mathbf{0 . 2 9 8}$ \\
Loss of Land and Soil Fertility & $\mathbf{7 2 . 0}$ & $\mathbf{2 1 . 8}$ & $\mathbf{0 . 9 1 2}$ \\
Shrinking size of Water bodies & $\mathbf{7 8 . 7}$ & $\mathbf{3 2 . 0}$ & \\
& & & \\
& & & \\
\end{tabular}

Source: Author's fieldwork, 2013.

c) Responses to Evidences of Climate Change

Responses to climate change evidences were in four key areas: water shortages, increases in temperature, loss of land and soil fertility and shortages of production and supplies. More than half of the respondents, about $76.0 \%, 57.0 \%, 70.0 \%, 51.0 \%$ and $86.0 \%$ have resorted to rain harvesting, long distance trek in search of safe drinking water, adoption of streams/springs as alternative water sources, sinking of boreholes/wells and controlled use/water reuse respectively during water shortages.

Subsequently, about $64.0 \%$ and $58.0 \%$ have resorted to relaxation under trees and wearing of light dresses during intense heat; $61.0 \%$ and $52.0 \%$ have used chemical fertilisers to boost farm produce and change from agro-based occupation into other occupation respectively due to loss of land and soil fertility; while $55.0 \%$ of the respondents have resorted into mixed cropping owing to shortages of food production and supplies (see table 2).

Table 2: Responses to Climate Change Evidences

\begin{tabular}{|c|c|c|c|}
\hline \multirow[t]{2}{*}{ Responses to Climate Change Evidences } & \multicolumn{2}{|c|}{ Responses } & \multirow[t]{2}{*}{ Test Results (p-value) } \\
\hline & Yes $(\%)$ & No $(\%)$ & \\
\hline Water Shortages & & & 0.087 \\
\hline $\begin{array}{ll} & \text { Rain Harvesting }\end{array}$ & 76.0 & 24.0 & \\
\hline Long distance trek & $\mathbf{5 7 . 0}$ & 43.0 & \\
\hline Stream/Springs adoption & 70.0 & 30.0 & \\
\hline Boreholes/Wells sinking & 51.0 & 49.0 & \\
\hline Controlled and Water Reuse & 86.0 & 14.0 & \\
\hline Increases in Temperature & & & 0.088 \\
\hline Relaxation under trees & 64.0 & 36.0 & \\
\hline Wearing light dresses & 58.0 & 42.0 & \\
\hline Tree planting & 33.0 & 67.0 & \\
\hline Use of fans/air-conditioners & 48.0 & 52.0 & \\
\hline Loss of Land and Soil Fertility & & & 0.084 \\
\hline - $\quad$ Use of chemical fertilisers & 61.0 & 39.0 & \\
\hline Use of organic manure & 28.0 & 72.0 & \\
\hline Mulching practices & 35.0 & 65.0 & \\
\hline Bush fallowing & 20.0 & 80.0 & \\
\hline Change from agro-based occupation & 52.0 & 48.0 & \\
\hline Food Production and Supply Shortages & & & 0.086 \\
\hline - $\quad$ Engage in subsistence farming & 42.0 & 58.0 & \\
\hline Use of food ripeners & 36.0 & 64.0 & \\
\hline Mixed cropping & 55.0 & 45.0 & \\
\hline Sale/Buying of crop on fields & 44.0 & 56.0 & \\
\hline
\end{tabular}

Source: Author's fieldwork, 2013.

\section{d) Test of Research Hypotheses}

The results reveal that there were significant differences in perception across political wards/health districts with overgrazing, settlement expansion and over-cropping (causes) with p-values of 0.049, 0.019 and 0.048 respectively. In a like manner, excessive dryness and reduction in food production and supplies (evidences) with p-values of 0.018 and 0.012 respectively did show that there were significant differences in perception across the wards (see table 1). All other causes and evidences of,and responses to the evidences of climate change had p-values greater than 0.05 which is the set level of significance; therefore we fail to reject the null hypotheses that there were no significance differences in perception across political wards/health districts.

By implication, at certain wards there were excessive grazing such that land was exposed to direct heating of the sun, consequently, global warming was enhanced. This has further promoted excessive dryness owing to removal of greeneries during settlement expansion and encroachment of farmlands. The removal of topmost soil and depletion of soil fertility have encouraged over-cropping in most parts of the study area in 
order to cover for reduction in food production and supplies. Therefore, conscious efforts must be made to forestall the challenges of soil fertility loss, global warming and heat waves.

\section{Conclusion And Recommendations}

To enhance the ability to further cope with the challenges of climate change, it is envisaged that the following recommendations be fortified through environmental education. People of Akinyele LGA need to understand the implications of their actions and inactions, equipped with the knowledge to salvage the future environment through environmental friendly actions of the present. Their willingness to rise to the challenges of fluctuations in climate becomes effectual if they are harnessed to enhanced security and rewards for doing so.

Lastly, contributing factors to involvements in activities that hamper the restoration of the climate to normalcy e.g. poverty; crude technology, over exploitation of natural resources and poor waste management among other things must be adequately addressed. Then, shall the earth be restored and enhanced to support the continuous existence of man and other living creatures.

For some of the observed evidences and problems of climate change, the following set of actions are suggested as step necessary to ameliorating the scourges of its impacts and thus enhance the ability of the local communities to further cope with the challenges of climate change.

\section{- Tree Planting Initiatives}

Some of the observed causes of climate change are related to change in temperature which finds its roots in seasonal variation, desertification, encroachment into forested land and accumulation of GHGs. However, in order to forestall the impacts, tree planting initiatives is envisioned such that the local communities will be encouraged through the planting of a tree per building technique. This will enhance the capacity of the Earth to further sink carbon dioxide which is a major GHG that increase global warming. Also, this will further strengthen the campaign against indiscriminate felling of trees and fuel wood gathering. For efficiency, compliance may be rewarded and appreciated and non-compliance may be prosecuted.

\section{- Conservation Practices}

In theory, planning is a discipline that has conservation as one of its tenets, most especially under development control practices and natural resources management. It is therefore, high time, that we stood the ground in protecting the ecosystem and biodiversity. This was in existence in the beginning but, it is far disintegrating in practice today. Though, allowance need be given to changes so as to upgrade lifestyle of rural populace yet, the characteristic nature (ecosystem and nature) should not be eroded.

Within Akinyele LGA, for instance, peri-urban areas are already losing their prominence for agriculture and are becoming centres of trade and commerce, transportation and educational institution. With the following comes clearing of forests and grass land; conversion of uses not minding conflicts, construction of route ways (tarred and concreted floors) which promote the chances of global warming let alone the disruption of the ecosystem wherein more plant and animal species are sent into extinction.

\section{- Embracing Landscape Planning}

Mostly when development projects are carried out within cities and peri-urban areas, the consciousness of the developer(s) is not linked with landscape planning. Planners need to ensure properties are well landscaped as alternative to greeneries wiped off. The landscape will not only beautify the scenery but also, provide the environment with good fragrance and capacity to sink carbon-dioxide.

\section{- Re-Introduction of Neighbourhood Park}

The relative fixity of land, its economic value and increasing demand for settlement expansion and other uses had fortified the disintegrating concern for neighbourhood parks. More importantly, now that land is given out to the highest bidder who holds it in his best profit maximizing interest. Most open spaces in periurban areas of Akinyele have been held in conflicting uses with pre-existing land uses.

Some of such lands are sold for fuel stations near original residential areas, some as trailer/bus parks and/or local market. Yet, the local communities need such neighbourhood parks for relaxation and games after day's toiling. This is reflective in the presence of some village squares where villagers observed their leisure in the evening. There is therefore, utmost need to prevent the conversion of available open spaces (village squares) from private interests which most often come at the detriment of the community.

\section{- Provision of Water Reservoirs/Channelizing Flood Plains}

In order to forestall shortages in water supply, the peri-urban communities have adopted different techniques and methods at their disposal e.g. adoption of streams and springs, long distance trek in search of wells and boreholes and also, rain harvest. Yet, these alternative sources of water are further threatened by 
seasonal changes and contamination of sources among others. With these alternatives sources the question of pressure by excess population and inadequate storage facilities still hold serious implications for their sustenance.

Therefore, this writer is of the opinion that as it were in some of the big cities like Ibadan, peri-urban areas should be given huge water reservoirs where water can be channelled, treated and preserved till the dry season. The flood plains can be channelized to store flood water which will be useful for irrigation and other purposes during dry season.

\section{- Prohibiting Bush Burning}

Management of the forest and grass lands should be upheld at local levels through fire prevention techniques such as planting of fire resistant tree species, thinning from below, prevention of gaps in forest canopy, education through news dailies, radio and TV broadcasts and extension services. Stricter laws should be enacted against deliberate bush burning and the community through Non Governmental Organizations (NGOs), Community Based Organizations (CBOs) and other voluntary organizations should be actively involved in policy making and enforcing against firewood gathering and crude methods of bush clearing.

\section{- Farm Practice Improvement}

In as much as it was discovered that farming pre-occupation is one of the major economic activities of the people of Akinyele LGA, it is therefore necessary to think on how the farming activities can be improved without necessarily jeopardising the climate. Hence, the writer opines that agricultural practices can be improved through the use of improved technology and drought resistant seedlings on the one hand while involvement of relevant government agencies is considered vital on the other hand so as to enhance soil survey, land evaluation, fertilizer testing and management. These will further strengthen extension services rendered by the agricultural officers to rural farmers. Lastly, irrigation agriculture can be encouraged in the peri-urban areas since the provision of water reservoirs has been suggested as one of the strategies to enhance residents' ability to further cope with challenges experienced agriculturally.

\section{- Liming water point sources}

One of the major challenges of water shortage, within Akinyele LGA is acid rain, when the $\mathrm{pH}$ value of water falls below 5; it is said to be acidic. These have got a lot of negative effects on plants life, nutrients in the soil are evaded e.g. calcium and magnesium, life in water in threatened. Also, building materials are evaded and rush because water has got its $\mathrm{pH}$ value reduced to between 2.0 to 4.5 through the dissolution of Sulphur and Nitrogen in water vapour. Therefore, both sulphuric and nitric acids were formed respectively. Hence, the use of renewable sources of energy is recommended to reduce the emission of Sulphur and Nitrogen. Liming of water point source is recommended as strategy to reduce the acidity of water at least, at the point sources such as streams, springs and wells.

\section{- Environmental Education and Management}

It is pertinent at this juncture to say that the major way-out of the challenges of climate change is to get the general public educated on issues pertaining to causes, evidences and problems emanating from human induced activities and possibly as it is done in other developed countries of the world, introducing nature studies and/or environmental management studies into the school's curriculum. This will not only enhance adequate information on climate change issues but, it will also equip every individual with detailed understanding of what to do in order to cope with the challenges of climate change (at the worst) and/or with ability to forestall the problems emanating in the present or in the nearest future.

\section{References}

[1]. Adeboyejo, A. T; Adejumobi, D. O and Kehinde, O. J (2011) 'Perception of Climate Change Issues and Household Response Patterns in Peri-Urban Areas of Ibadan, Nigeria' The International Journal of Climate Change: Impacts and Responses, Vol. 2 No. 4 2011; http://www.Climate-Journal.com.

[2]. Adelekan, I.O and Gbadegesin, A.S (2004) 'Analysis of the Public Perception of Climate Change Issues in an Indigenous African City' International Journal of Environmental Studies, Vol. 62, No. 1 Feb. 2005 pp 115-124.

[3]. Aina, F.O.A (1990) "Keynote Address by the Direct/Chief Executive FEPA at the Workshop on Environmental Education for Secondary Schools Teachers" organized by Nigerian Conservation Foundation and Institute of Education University of Lagos

[4]. 13th -15 th June, 1990.

[5]. Barrow, C. J (1991) Land Degradation: Development and Breakdown of Terrestrial Environment. Cambridge University Press, Great Britain.

[6]. Bayero, A (2004) 'Environmental Degradation: Causes, Effects, Implications for Resource Conservation and the Future' in Egunjobi, O. A; Kayode, J; Faluyi, M. A; Mukolu, A and Afolabi, O (eds.) Environmental Degradation, Reclamation, Conservation and Pollution Control for the Rural Women and the Youth. The Proceedings of the National Practical Training Workshop of EDAPW and NATCOM/UNESCO held at University of Ado Ekiti on 24th - 26th August, 2004.

[7]. Bush, M. B (2000) Ecology of a Changing Planet (2nd Edition) Prentice Hall Upper Saddle River, New Jersey 07458. 
[8]. Cunningham, W. P and Cunningham, M. A (2004) Principles of Environmental Science: Inquiry and Applications (2ndEdition)McGraw Hill Higher Education, WI New York, San Francisco.

[9]. Duruzoechi N. F. (2001) "Public Participation in Sustainable Urban Planning and Development": in Duruzoechi (ed.) Town Planning Practice in Nigeria pp. 79-96 Krisdon Graphic Ltd. Owerri Nigeria.

[10]. EDAPW and NATCOM/UNESCO (2004) in Egunjobi, O. A; Kayode, J; Faluyi, M. A; Mukolu, A and Afolabi, O (eds.) Environmental Degradation, Reclamation, Conservation and Pollut6ion Control for the Rural Women and the Youth. The Proceedings of the National Practical Training Workshop of EDAPW and NATCOM/UNESCO held at University of Ado Ekiti on 24th - 26th August, 2004.

[11]. Egunjobi 'Layi (1993) "Issues in Environmental Management in Nigeria”. The Environmentalist Journal: Vol. 13 No. 1 pp. 33 -40.

[12]. FAO (1997) 'State of the World's Forests 1997', Food and Agriculture Organization Report, FAO Rome, pp 200.

[13]. Fielding, G. J (1974) Geography as Social Science: Harper and Row Publishers, New York pp282.

[14]. Fuwape, J. A (2004) 'Deforestation and Its Impact on Tgropical Forest' in Egunjobi, O. A; Kayode, J; Faluyi, M. A; Mukolu, A and Afolabi, O (eds.) Environmental Degradation, Reclamation, Conservation and Pollution Control for the Rural Women and the Youth. The Proceedings of the National Practical Training Workshop of EDAPW and NATCOM/UNESCO held at University of Ado Ekiti on 24th - 26th August, 2004.

[15]. Goudie, A (1990) The Human Impacts on the Natural Environment, 3rd Edition, Cambridge, Mass.: MIT Press.

[16]. Intergovernmental Panel on Climate Change (IPCC), http://www.ipcc.ch/about/index.htm. Retrieved on 2008-11-29.

[17]. Jones, N; Arnott, S and Douglas, O (1998) 'The Human Ecosystems of the Niger-Delta', Benin City: An ERA Handbook.

[18]. Kate, R.W and Torrie, R. D (1998) Global Changes in Local Places, Environment, 40(2); pp 39-41.

[19]. McKinney, M. L and Schoch, R. M (1998) Environmental Science: Systems and Solutions (Web enhanced edition) Jones and Barlett Publishers, Sudbury, Massachusetts.

[20]. NCF (2004) A Goodwill Message Delivered by Nigerian Conservation Foundation Representative at the Workshop held at UNAD Ado Ekiti by EDAPW/NATCOM on 24th-26th August, 2004.

[21]. Noibi, A.S (1990) "Challenges of Environmental Education in Nigerian schools": An Address delivered at the workshop on Environmental Education for Secondary Schools Teachers 13th - 15th June, 1990.

[22]. Ogundipe, O (2006) Introduction to Environmental Issues: Causes, Effects and Solutions: Ikofa Commercial Press Ltd. Shomolu Lagos.

[23]. Okali, D (2004) 'Environmental Management in the New Millennium’ A Keynote Address Delivered in Egunjobi, O. A; Kayode, J; Faluyi, M. A; Mukolu, A and Afolabi, O (eds.) Environmental Degradation, Reclamation, Conservation and Pollution Control for the Rural Women and the Youth. The Proceedings of the National Practical Training Workshop of EDAPW and NATCOM/UNESCO held at University of Ado Ekiti on 24th - 26th August, 2004.

[24]. Pearce, F (1996) 'Tropical Smogs Rival Big City Smoke' New Scientist, May 18th, 1996 Vol. 4.

[25]. Shah, Anup (2007) Global Warming, Spin and Media: http:// www.globalissues.org/EnvIssues/Global Warming/media. asp

[26]. Shah, Anup (2007) Climate Change and Global Warming: http:// www.globalissues.org/EnvIssues/Global Warming/population. asp

[27]. Shah, Anup (2002) Carbon Sinks, Forests and Climate Change: http:// www.globalissues.org/EnvIssues/Global Warming/forests. $\underline{\text { asp }}$

[28]. UNEP (1997) Global Environment Outlook UNEP, Nairobi, Kenya. Pp264

[29]. WDR (2003) 'Global Problems and Local Concerns' A World Bank Publication. http://econ.worldbank.org/wdr/wdr2003/

[30]. Wikipedia (2007) http://en.wikipedia.org/wiki/Climate Change.

[31]. World Resource Institute (1994) World Resources 1994-95, New York: Oxford University Press 